\title{
In iure cessio hereditatis
}

\section{Veronika Kleňová}

Johannes Kepler Universität Linz

Kontaktný e-mail:v.klenova@gmail.com

\section{In iure cessio hereditatis}

\begin{abstract}
:
In iure cessio hereditatis ante aditionem could only be performed by a voluntary intestate heir. An heir appointed in the testament did not have such a right, because the in iure cessio hereditatis ante aditionem was an extraordinary means to prevent that the deceased remained without heirs. Post aditionem could be in iure cessio hereditatis exercised by both heres legitimus and heres testamento scriptus.

The object of the in iure cessio hereditatis ante aditionem was a delata hereditas the right to be an heir. The transferee became an heir as if he himself were called to be an heir. He became an heir immediately due to the very in iure cessio hereditatis. He did not have to perform an additional aditio.

In accordance with the semel heres semper heres rule, it was impossible to transfer ius successionis after the transferor became an heir through aditio. Via in iure cessio hereditatis post aditionem could only be transferred those components of hereditas that were admissible object of in iure cessio; that were corpora hereditaria but not the obligations. The transferor remained liable to creditors and the debitores hereditarii were released.

Sabinians held that the heredes sui et necessarii cannot perform in iure cessio hereditatis. The reason was that the in iure cessio hereditatis was considered to be a rejection of the inheritance, and thus incompatible with the position of the necessary heir. Proculians contended the in iure cessio to be valid with the same effect as if it had been done by a voluntary heir after acceptance of an inheritance. The dispute was relating only to sui (not to slaves as necessarii heredes). The proculians intended to get the position of the sui et necessarii closer to that of heredes voluntarii. It is not surprising, if one considers that the praetor granted to sui a beneficium abstinendi as a means by which the sui could achieve a similar result of a rejection of an inheritance. The opinion of the proculians did not prevail.
\end{abstract}




\begin{abstract}
Keywords:
in iure cessio hereditatis; hereditas; necessary heirs; voluntary heirs; repudiation of an inheritance
\end{abstract}

\begin{abstract}
Kl'účové slová:
in iure cessio hereditatis; hereditas; dobrovol'ní dedičia; nevyhnutní dedičia; odmietnutie dedičstva
\end{abstract}

DOI: $10.14712 / 2464689 X .2018 .26$

Financovanie: Príspevok je výstupom z projektu VEGA 1/0495/11.

Základným prameňom poznania in iure cessionis hereditatis ${ }^{1}$ sú Gaiove Institutiones. Gaius spomína in iure cesiu pozostalosti na dvoch miestach: v druhej knihe (Inst. 2, 34-37) v rámci výkladu o prevode rerum incorporalium ${ }^{2}$ a po druhýkrát v tretej knihe (Inst. 3, 85-87) pri predstavovaní intestátneho dedenia a niektorých d’alších foriem sukcesie. Skromnejší výklad podáva aj Ulp. lib. sing. 19, 12-15 v časti s názvom De dominiis

1 Ad in iure cessionem hereditatis pozri aj AMBROSINO, R. In iure cessio hereditatis. Spunti per la valutazione della hereditas. SDHI, 1944, 10, s. 1 a nasl.; ALBANESE, B. Gai. II, 34-37 e l'in iure cessio hereditatis. In: Scritti giuridici. I. Palermo: G. B. Palumbo \& C. Editore, 1991, s. 43-77; BAVIERA, G. Le due scuole dei giureconsulti romani. Firenze: Fratelli Cammelli, 1898, s. 112 a nasl.; BETTI, E. "In iure cessio hereditatis", "successio in ius" e titolo di "heres". In: Studi in onore di Siro Solazzi. Napoli: E. Jovene,1948, s. 594 a nasl.; DE MARTINO, F. Nota in tema di «in iure cessio hereditatis». In: Studi in onore di Siro Solazzi. Napoli: E. Jovene,1948, s. 568 a nasl.; FALCHI, G. L. Le controversie tra sabiniani e proculiani. Milano: Dott. A. Giuffrè editore, 1981, s. 141 a nasl.; LA PIRA, G. La successione ereditaria intestata e contro il testamento in diritto romano. Firenze: Vallecchi editore, 1930, s. 144 a nasl.; LÜBTOW, U. Die Übertragung des Rechts zur Antretung der Erbschaft und die Weitervererbung des erworbenen Nachlasses. In: Studi in onore di Gaetano Scherillo. I. Milano: La Goliardica, 1972, s. 327 a nasl.; ROBBE, U. La «hereditas iacet» e il significato della «hereditas» in diritto romano. I. Milano: Dott. A. Giuffrè Editore 1975, s. 435-500; ROBBE, U. Le definizioni delle fonti della hereditas ed i suoi due significati. La in iure cessio hereditatis. In: Studi in memoria di Guido Donatuti. III. Milano: La Goliardica, 1973, s. 1031 a nasl; SCHERILLO, G. La in iure cessio dell'eredità. In: Scritti giuridici in onore di Francesco Carnelutti. IV. Padova: CEDAM, 1950, s. 255 a nasl.; SOLAZZI, S. Diritto ereditario romano. I. Napoli: Nicola Jovene \& C. Editori, 1932, s. 251 a nasl.; SOLAZZI, S. L' "in iure cessio hereditatis" e la natura dell'antica "hereditas". IURA, 1952, 3, s. 21 a nasl; TORRENT, A. Venditio hereditatis. Salamanca: Universidad de Salamanca, 1966, s. 131 a nasl.; TORRENT, A. Cronología, finalidad y desaparición de la in iure cessio hereditatis. In: Studi in onore di Edoardo Volterra. Vol. III. Milano: Dott. A. Giuffré, 1971, s. 237 a nasl.; VOCI, P. Diritto ereditario romano. Vol. primo. Introduzione parte generale. Milano: Dott. A. Giuffré, 1967, s. 98 a nasl.

2 Medzi ktoré podla Gaia patrili hereditas, ususfructus, obligationes a servitutes. Gai. Inst. 2, 14: Incorporales sunt, quae tangi non possunt, qualia sunt ea, quae <in $>$ iure consistunt, sicut hereditas ususfructus obligationes quoquo modo contractae. nec ad rem per<tinet, quod in hereditate res corporales con $>$ tinentur, et fructus qui ex fundo percipiuntur, corporales sunt, et quod ex aliqua obligatione nobis debetur, id || plerumque corporale est, veluti fundus homo pecunia: nam ipsum ius successionis et ipsum ius utendi fruendi et ipsum ius obligationis incorporale est. eodem numero sunt iura praediorum urbanorum et rusticorum. [...] haec iura praediorum (?) tam urbanorum quam rusticorum servitutes vocantur. Cit. podla Gai Institutiones secundum Codicis Veronensis apographum studemundianum et reliquias in Aegypto repertas. Iterum edidit M. David. Editio minor. Editio secunda. Studia Gaiana ed. M. David, R. Feenstra, H. L. W. Nelson, vol. I. 1964. Citovanú edíciu používam i v d’alšom texte. 
et adquisitionibus rerum. In iure cessione prevádzal cedent hereditatem na cesionára. ${ }^{3}$ Pozostalost' mohla byt' in iure cedovaná bud' pred tým, než bola prijatá, alebo až po adícii. ${ }^{4}$ Napriek tomu, že v obidvoch prípadoch bola objektom in iure cesie hereditas, jej účinky neboli totožné. Zhodný nebol ani okruh osôb, ktoré boli oprávnené k jej uskutočneniu.

\section{In iure cessio hereditatis ante aditionem}

Gai. Inst. 2, 35: Nam si is, ad quem ab intestato legitimo iure pertinet hereditas, in iure eam alii ante aditionem cedat, id est antequam heres extiterit, proinde fit heres is, cui in iure cesserit, ac si ipse per legem ad hereditatem vocatus esset. [...]

Gai. Inst. 2, 36: Testamento autem scriptus heres ante aditam quidem hereditatem in iure cedendo eam alii nihil agit; [...]

Gai. Inst. 3, 85: Item si legitimam hereditatem heres, antequam cernat aut pro herede gerat, alii in iure cedat, pleno iure fit ille heres, cui cessa est hereditas, proinde ac si ipse per legem ad hereditatem vocaretur. [...]

Gai. Inst. 3, 86: [...] testamento scriptus heres, [...]; ante aditam vero hereditatem cedendo nihil agit.

Ulp. lib. sing. 19, 13: Antequam adeatur, in iure cedi potest legitimo ab herede; posteaquam adita est, tam a legitimo quam ab eo, qui testamento heres scriptus est.

Ulp. lib. sing. 19, 14: Si, antequam adeatur, hereditas in iure cessa sit, proinde heres fit, cui cessa est, ac si ipse heres legitimus esset; [...]

Pred prijatím pozostalosti mohol in iure cessionem hereditatis vykonat' iba ten, komu bola pozostalost' ponúknutá ab intestato (heres legitimus). V dôsledku takto vykonanej in iure cesie sa dedičom podl'a civilného práva (pleno iure) stal ten (fit heres is), komu bola pozostalost' postúpená, a to práve tak, akoby bol sám k pozostalosti zákonom povolaný.

In iure cesii vykonanej pred prijatím pozostalosti delátom ab intestato som sa venovala na inom mieste. ${ }^{5}$ Stručne preto iba zhrniem závery, na ktoré budem v d'alšom obsahu nadväzovat'.

In iure cessio hereditatis ante aditionem bola mimoriadnym prostriedkom, ktorý umožňoval preklenút' nevýhody spôsobené neprípustnost'ou sukcesívnej delácie pri intestátnom dedení podl'a Zákona XII tabúl'. Najstaršie rímske právo ešte nedokázalo rešpektovat' myšlienku, že univerzálnym nástupcom poručitel'a má byt' niekto, v prospech koho právna možnost' stat' sa dedičom vznikla až s určitým časovým odstupom od zániku právnej subjektivity poručitel'a ako pôvodného nositel'a práv a povinností. Pri intestátnom dedení bola preto vylúčená sukcesívna delácia tak v rámci triedy (successio graduum), ako aj medzi

3 SOLAZZI, Diritto ereditario romano. I., s. 252-253: v časoch Gaia sa in iure cessio hereditatis pravdepodobne uskutočňovala $\mathrm{v}$ dedičskom procese. Cesionár pred prétorom vzniesol petitionem hereditatis proti pravému dedičovi (delátovi). Tento mlčal, v dôsledku čoho magistrát vyslovil addictio dedičstva v prospech cesionára (porov. Gai. Inst. 2, 24). Žalobca vyhlasoval hanc hereditatem meam esse aio ex iure Quiritium, inak by Gaius hovoril o familiam cedere tak, ako hovorí o familiam mancipare. Neskôr známa in iure cessio hereditatis bola pôvodne in iure cessio familiae. K tomu pozri aj SOLAZZI, S. L'. "in iure cessio hereditatis" e la natura dell'antica "hereditas", s. 35 a nasl.

$4 \quad$ Ulp. lib. sing. 19, 12: Hereditas in iure ceditur vel antequam adeatur, vel posteaquam adita fuerit.

5 KLEŇOVÁ, V. Delácia dedičstva v rímskom práve. In: MACH, P. - PEKARIK, M. - VLADÁR, V. (eds.). Constans et perpetua voluntas. Pocta Petrovi Blahovi $k$ 75. narodeninám. Trnava: Trnavská univerzita v Trnave, Právnická fakulta, 2014, s. 281-311. 
jednotlivými triedami (successio ordinum). ${ }^{6}$ Ak heres voluntarius, v prospech ktorého delácia nastúpila smrt'ou poručitel'a, pozostalost' neprijal, prípadne pred adíciou zomrel, poručitel' zostal iure civili bez dediča, ${ }^{7}$ pretože d'alšia delácia už bola vylúčená. Tejto situácii bolo možné predíst' prostredníctvom in iure cessionis hereditatis ante aditionem: ak (pôvodný) delát ante aditionem postúpil pozostalost' inému, stal sa tento sám dedičom, akoby sa delácia vzt'ahovala priamo na neho. ${ }^{8}$ Uplatnila sa fikcia, že v čase smrti poručitel'a bol povolaný cesionár. Delát takto prevádzal na iného vzniknutú a jemu patriacu, lež ešte nevyužitú, právnu možnost' byt' dedičom. V prospech cesionára sa neuskutočňovala nová delácia, nedochádzalo k oneskorenej delácii, lež išlo o tú istú deláciu, to isté povolanie, ktoré sa pôvodne vzt’ahovalo na niekoho iného. Právo pripustilo takýto výnimočný prostriedok za súčasného rešpektovania princípu, v zmysle ktorého heres môže byt' iba ten, komu právna možnost' stat' sa dedičom vznikla v okamihu smrti poručitel'a. Takéto účinky však nemala in iure cessio hereditatis vykonaná dobrovol'ným dedičom po adícii dedičstva, ani in iure cessio, ktorú by uskutočnil pred prijatím dedičstva delát povolaný testamentom. V obidvoch prípadoch totiž in iure cessio postrádala punc nevyhnutnosti, nakol'ko (bezprostredne) nehrozilo, že poručitel' zostane bez dediča. V prvom prípade sa „,cedent“ už dedičom stal. V prípade druhom, ak by delát ex testamento dedičstvo aj odmietol, pozostalost' by sa ponúkla substitútovi, prípadne intestátnym dedičom a in iure cessio hereditatis by sa pripustila až vtedy, ak by zákonom boli k dedeniu povolaní dedičia dobrovol'ní. Tol'ko, pokial' ide o závery predchádzajúcej štúdie.

Delát ex testamento pred adíciou in iure cessionem vykonat' nemohol. S deláciou nemohol slobodne disponovat' aj z toho dôvodu, že by tým v rozpore s poručitel'ovou vôl'ou mohol o možnost' stat' sa dedičom obrat' eventuálnych substitútov. ${ }^{9}$ Pokial' poručitel' niekomu takúto možnost' priznat' chcel, prichádzal do úvahy iný prostriedok, ktorým mohol dosiahnut' podobný výsledok: inštitúcia cudzieho otroka. Ak poručitel' v testamente ustanovil za dediča cudzieho otroka, pričom tento jeho právny status poznal, ${ }^{10}$ musel počítat' s tým, že tak ako môže byt' servus prepustený na slobodu, tak ho môže vlastník aj scudzit'. V závislosti od toho by sa dedičom v prvom prípade stal otrok sám, v druhom prípade ten, komu bude servus patrit' v čase prijatia dedičstva. ${ }^{11} \mathrm{~V}$ tejto súvislosti Gaius uvádza:

6 Testamentárna dedičská postupnost' vznikla neskôr. Až pri jej vzniku sa uznala sukcesívna delácia, najskôr pri prechode od testamentárneho $\mathrm{k}$ intestátnemu dedeniu, zakrátko i v rámci samotného testamentárneho dedenia v podobe substitúcií.

7 Úzukapient pro herede sa vydržaním nestával dedičom (heres), pretože mu chýbal delačný dôvod, na základe ktorého by mu vznikla právna možnost' byt' dedičom. Vydržaním pro herede mohol nadobudnút' iba hereditatem - súhrn vecí, práv a povinností, ktoré patrili poručitel'ovi, nie však aj postavenie dediča.

$8 \mathrm{~K}$ objetu in iure cessionis ROBBE, La «hereditas iacet» e il significato della «hereditas» in diritto romano. I., s. 440; 464-465.

9 Podobne KOEPPEN, A. Lehrbuch des heutigen römischen Erbrechts. Würzburg: Adalbert Stuber's Verlagsbuchhandlung, 1895, s. 142-143; KASER, M. Das römische Privatrecht. 1. Absch. Das altrömische, das vorklassische und klassische Recht. München: C. H. Beck, 1971, s. 722: „Der Testamentserbe ist dazu nicht befugt, weil der Wille des Erblassers nur ihn als Erben ausersehen hat."

10 K omylu poručitel'a v statuse ustanoveného dediča pozri KLEŇOVÁ, V. Substitutio vulgaris a sloboda vôle v práve rímskom. V̌̌eobecné náhradníctvo v prameňoch rímskeho práva s dôrazom na justiniánske Digesta. Plzeň: Aleš Čeněk 2013, s. 118-127.

11 Gai. Inst. 2, 188: [...] quodsi alienatus sit, iussu novi domini adire hereditatem debet. qua ratione per eum dominus fit heres: [...]. 
Gai. Inst. 2, 189: Alienus quoque servus heres institutus, si in eadem causa duraverit, iussu domini hereditatem adire debet; si vero alienatus ab eo fuerit aut vivo testatore aut post mortem eius, antequam cernat, debet iussu novi domini cernere; si vero manumissus est, suo arbitrio adire hereditatem potest.

Cudzí otrok, ktorý bol v testamente ustanovený za dediča, mohol prijat' dedičstvo iba na príkaz svojho vlastníka. Ak by ho pôvodný vlastník scudzil, či už za života testátora alebo po jeho smrti pred tým, ako dedičstvo prijal, musí otrok vykonat' adíciu na príkaz vlastníka nového. ${ }^{12}$ Ak by ho vlastník prepustil na slobodu, môže dedičstvo prijat' podl’a vlastného uváženia.

Otrok teda mohol byt' scudzený aj po smrti poručitel'a pred tým, ako na príkaz vlastníka dedičstvo prijal. ${ }^{13}$ Z Gaiovho textu nevyplýva, že by sa scudzenie nemohlo uskutočnit’ po delácii dedičstva. Slová antequam cernat naopak nasvedčujú skôr tomu, že Gaius predpokladal už nastavšiu deláciu. Vo vzt’ahu k otázke, kto prostredníctvom otrokom vykonanej adície nadobudne dedičstvo, je rozhodujúce, komu bude otrok v čase adície patrit' (na koho príkaz dedičstvo prijme).

Prostredníctvom inštitúcie cudzieho otroka mohol poručitel' jeho vlastníkovi umožnit' prevod už nastúpenej delácie aj v prípade testamentárneho povolania $\mathrm{k}$ dedeniu. Tak sa dosiahol účinok podobný in iure cesii, ktorú by delát ex testamento vykonal po delácii dedičstva, lež pred jeho prijatím. Dedičom sa nemusel stat' ten, kto bol vlastníkom otroka v čase delácie, lež vlastník nový, ktorý otroka nadobudol po nastavšej delácii. ${ }^{14}$

Ak pôvodný vlastník post mortem testatoris otroka scudzil, nový vlastník dedičstvo nenadobudol už v dôsledku nadobudnutia vlastníckeho práva k otrokovi, lež až v momente, ked' otrok na jeho príkaz hereditatem prijal (si vero alienatus ab eo fuerit post mortem eius, antequam cernat, debet iussu novi domini cernere). Otázkou zostáva, v ktorom okamihu sa dedičom stal cesionár v prípade in iure cessionis hereditatis vykonanej ante aditionem. In iure cessione ante aditionem prevádzal cedent na cesionára právnu možnost' byt' dedičom, prevádzal delatam hereditatem. Sú tak dve možnosti: 1) Cesionár v dôsledku in iure cessionis nadobudol právo vstúpit' do pozície poručitel'a, ktoré, aby sa realizovalo, muselo byt' ešte doplnené následnou adíciou vykonanou po in iure cesii. Alebo, 2) pro-

12 Porov. aj Iavolenus 1 ex post. Lab. D. 29, 2, 62, 1. K predaju otroka, ktorý bol ustanovený za dediča pozri WIMMER, M. Sklavenverkauf und „mitwandernde“ Delationen. ZSS, 2004, 121, s. 379 a nasl.

13 Ulp. lib. sing., ktorá obsahuje fragment s obdobnou problematikou, však možnost' aut post mortem eius [sc. testatoris], antequam cernat, nespomína. Ulp. lib. sing. 22, 13: Alienus servus heres institutus si quidem in ea causa permanserit, iussu domini debet hereditatem adire; quod si vivo testatore manumissus aut alienatus a domino fuerit, aut suo arbitrio aut iussu emptoris poterit adire hereditatem. Otázne preto je, či autor ono aut post mortem eius [sc. testatoris], antequam cernat neuvádza úmyselne, pretože takáto možnost' v jeho dobe do úvahy neprichádzala, alebo ide o neúmyselné vypadnutie textu, ku ktorému došlo pri prepisovaní diela. Skôr pre neúmyselný výpadok AVENARIUS, M. Der pseudo-ulpianische liber singularis regularum. Entstehung, Eigenart und Überlieferung einer hochklassischen Juristenschrift. Analyse, Neuedition und deutsche Übersetzung. Göttingen: Wallstein Verlag 2005, s. 416: „Falls die Aussage unseres Textes insoweit unvollständig ist, könnte dies auf einen unabsichtlichen Textverlust zurückgehen. Wenn die Mitteilung ebenso wie bei Gaius auch in der Vorlage des Regelwerks Teil einer Aufzählung gewesen ist (aut ... aut), dann bestünde Anlass für die Vermutung eines homoioteleutischen Ausfalls.“

14 Otrok bol „scudzitel'ným delátom“ (,,veräusserlicher Delat“); tak KOEPPEN, A. Lehrbuch des heutigen römischen Erbrechts. Würzburg: Adalbert Stuber's Verlagsbuchhandlung, 1895, s. 143, p. 1. 
stredníctvom in iure cessionis hereditatis sa cesionár stal dedičom ihned'; dodatočná adícia už nebola potrebná.

Pokial' ide o možnost’ prvú, táto by so sebou prinášala dve, domnievam sa, nie vel'mi žiaduce konzekvencie. Ak by cesionár v dôsledku in iure cessionis nadobudol iba právnu možnost' stat' sa dedičom, pozostalost' by bola bez dediča až do času, kým by dedičstvo prijal. Eventuálne by tak mohlo dochádzat' k d’alšiemu predlžovaniu doby, v ktorej neexistoval poručitel'ov sukcesor. Navyše by sa mohlo stat', že cesionár by adíciu nevykonal vôbec, pretože by pred tým zomrel, prípadne by mu v prijatí dedičstva natrvalo zabránili iné okolnosti. Napriek tomu, že bola uskutočnená in iure cessio hereditatis, tento mimoriadny prostriedok, ktorý mal zabránit' práve tomu, aby poručitel' nezostal bez dediča, neviedlo by to k uspokojivému záveru. Okrem toho, ak by cesionár in iure cessione nadobudol právo z delácie, ktoré sa v jeho osobe nerealizovalo ihned' cesiou, čo mu bránilo, toto právo opät' scudzit' na d'alšieho? V zachovaných prameňoch takáto možnost' dosvedčená nie je pravdepodobne preto, že d’alšie scudzenie práva z delácie cesionárom bolo vylúčené.

Ak by sa vyžadovalo, aby cesionár po in iure cesii vykonal ešte samostatnú adíciu, bol by to Gaius vo svojej učebnici pravdepodobne uviedol. Čo bránilo tomu, aby bola cesia vo vzt’ahu k cesionárovi posudzovaná zároveň aj ako pro herede gestio? ${ }^{15}$ In iure cessione ante aditionem cedent prejavoval vôl'u, že sa v prospech cesionára vzdáva pozostalosti, ktorá mu bola ponúknutá a cesionár vyjadroval svoju vôl'u, že delatam hereditatem, ktorú mu cedent prevádzal, prijíma. Takéto ponímanie plne korešpondovalo s prezumovaným účelom, ktorému in iure cessio ante aditionem slúžila - výnimočne prípustným prevodom delácie zabránit' tomu, aby pozostalost' zostala bez dediča. V situácii, ked' hrozila neexistencia dediča, uznal právny poriadok možnost', previest' delatam hereditatem tomu, kto sa dedičom poručitel'a stat' chcel. Vôl'u byt' dedičom pritom cesionár prejavil svojou participáciou na in iure cesii.

\section{In iure cessio post aditionem}

Gai. Inst. 2, 35: Nam si is, ad quem ab intestato legitimo iure pertinet hereditas, in iure eam alii ante aditionem cedat, id est antequam heres extiterit, proinde fit heres is, cui in iure cesserit, ac si ipse per legem ad hereditatem vocatus esset. post obligationem vero si cesserit, nihilo minus ipse || heres permanet et ob id creditoribus tenebitur; debita vero pereunt eoque modo debitores hereditarii lucrum faciunt; corpora vero eius hereditatis proinde transeunt ad eum, cui cessa est hereditas, ac si ei singula in iure cessa fuissent.

Gai. Inst. 2, 36: Testamento autem scriptus heres ante aditam quidem hereditatem in iure cedendo eam alii nihil agit; postea vero quam adierit si cedat, ea accidunt, quae proxime diximus de eo, ad quem ab intestato legitimo iure pertinet hereditas, si post obligationem $<$ in $>$ iure cedat.

15 Tak aj LÜBTOW, U. Die Übertragung des Rechts zur Antretung der Erbschaft und die Weitervererbung des erworbenen Nachlasses. In: Studi in onore di Gaetano Scherillo. I. Milano: La Goliardica, 1972, s. 329-330: osobitná adícia sa nevyžadovala po uznaní pro herede gestionis. V staršom práve musel cesionár vykonat' dodatočnú adíciu formou cretionis. Podobne KINCL, J. - URFUS, V. - SKŘEJPEK, M. Řimské právo. 1. vyd. Praha: C. H. Beck, 1995, s. 296: „Injurecessí se nabyvatel stával prrímo civilním dědicem, nebot’ injurecesse se posuzovala jako přijetí dědictví, jak to odpovídalo faktu, že v průběhu injurecesse nabyvatel pozůstalost vlastně vindikoval.“ 
Gai. Inst. 3, 85: Item si legitimam hereditatem heres, antequam cernat aut pro herede gerat, alii in iure cedat, pleno iure fit ille heres, cui cessa est hereditas, proinde ac si ipse per legem ad hereditatem vocaretur. quodsi postea quam heres extiterit, cesserit, adhuc heres manet et ob id [a] creditoribus ipse tenebitur; sed res corporales transferet, proinde ac si singulas in iure cessisset, debita vero pereunt, eoque modo debitores hereditarii lucrum faciunt.

Gai. Inst. 3, 86: Idem iuris est, si testamento scriptus heres, postea quam heres extiterit, in iure cesserit hereditatem; ante aditam vero hereditatem cedendo nihil agit.

Ulp. lib. sing. 19, 14: Si, antequam adeatur, hereditas in iure cessa sit, proinde heres fit, cui cessa est, ac si ipse heres legitimus esset; quod si posteaquam adita fuerit, in iure cessa sit, is, qui cessit, permanet heres, et ob id creditoribus defuncti manet obligatus; debita vero pereunt, id est debitores defuncti liberantur.

Ulp. lib. sing. 19, 15: Res autem corporales, quasi singulae in iure cessae essent, transeunt ad eum, cui cessa est hereditas.

V druhej časti Inst. 2, 35 a 3, 85, ktorá sa ešte stále vzt'ahuje na dediča povolaného zákonom, Gaius uvádza, že ak by tento cedoval pozostalost' ${ }^{16}$ po tom, ako sa stal dedičom, nad'alej dedičom zostane a bude preto sám povinný voči pozostalostným veritel'om. In iure cessione však prevedie res corporales, práve tak, akoby ich bol býval in iure cedoval jednotlivo. Dlhy zaniknú a tým pozostalostní dlžníci dosiahnu zisk.

Rovnaké následky vyvolá aj in iure cessio hereditatis uskutočnená testamentárnym dedičom po prijatí dedičstva. Hoci pred adíciou s pozostalost'ou a teda s právnou možnost'ou stat' sa dedičom disponovat' nemohol, posteaquam heres extiterit bolo jeho konanie rešpektované.

Ak bola cesia vykonaná po adícii dedičstva, zostal cedent v súlade so zásadou semel heres semper heres dedičom. Objekt cesie sa preto musel odlišovat' od toho, ktorý sa prevádzal pred prijatím dedičstva. In iure cessione hereditatis vykonanou pred adíciou heres legitimus disponoval s právnou možnost'ou stat' sa dedičom, prevádzal ius successionis, ktoré mu deláciou vzniklo. Cedent dedičstvo neprijal, dedičom sa stal až cesionár, ktorý v dôsledku toho nadobudol pozostalost' ako celok. Až tým sa hereditas, dovtedy právne existujúca ako jednotný celok, v osobe cesionára rozložila na jednotlivé práva, povinnosti a corpora. ${ }^{17}$ Ak ale in iure cessionem hereditatis vykonal cedent po adícii, nemohol už previest' pozostalost' ako celok, pretože táto sa v jeho osobe už rozložila na svoje jednotlivé zložky. In iure cessione mohol previest' iba izolované komponenty hereditatis, ktoré teraz existovali samostatne a patrili cedentovi - dedičovi.

16 Ani v Inst. 3, 85, ani v Inst. 2, 35 vo vzt’ahu k in iure cesii vykonanej po adícii nie je výslovne uvedený jej objekt. To, že i v týchto prípadoch bola objektom in iure cessionis pozostalost' - hereditas -, možno usúdit' z Ulp. lib. sing. 19, 14: si, antequam adeatur, hereditas in iure cessa sit, [...]; quod si posteaquam adita fuerit, in iure cessa sit, [...]. Particípium adita sa viaže na hereditas. Ešte zretel'nejšie to vyplýva z Inst. 3, 86: Idem iuris est, si testamento scriptus heres, postea quam heres extiterit, in iure cesserit hereditatem; ante aditam vero hereditatem cedendo nihil agit. Taktiež zo záveru Inst. 2, 35: corpora vero eius hereditatis proinde transeunt ad eum, cui cessa est hereditas. K tomu pozri aj ALBANESE, c. d., s. 50 a nasl.

17 Pozri aj VOCI, c. d., s. 151 a nasl. 
Obligationes predmetom in iure cessionis byt' nemohli, ${ }^{18}$ preto cesionár zo zložiek pôvodne patriacich do hereditatis, nadobúdal iba corpora eius hereditatis, proinde ac si ei singula in iure cessa fuissent. ${ }^{19}$ Pretože sa i po prijatí dedičstva cedovala (akoby) pozostalost', bolo možné jedným úkonom na cesionára previest' všetky jej corpora. Nemuseli byt' prevádzané jednotlivo. Cedentove povinnosti voči pozostalostným veritel'om zostali zachované, bol povinný ich splnit'. ${ }^{20}$

Zatial' čo dlhy pozostalosti v osobe cedenta ako dlžníka nad'alej zostali existovat', pozostalostné pohl'adávky zanikli a pozostalostní dlžníci boli oslobodení. Hoci je rozdielny osud pozostalostných pohl'adávok na jednej strane a pozostalostných dlhov na strane druhej t’ažko pochopitel'ný, ${ }^{21}$ Gaius o dôvodoch mlčí. Zánik pozostalostných pohl'adávok prekvapuje o to viac, že k nemu nedochádzalo ani pri predaji pozostalosti (venditio hereditatis). ${ }^{22}$ Zjavne bola in iure cessio hereditatis posudzovaná odlišne ako kauzálne scudzenie ${ }^{23}$ formou predaja. Vo svojej abstraktnosti bola in iure cessio hereditatis pravdepodobne interpretovaná ako zrieknutie sa dedičstva, ktoré v sebe prirodzene zahŕňalo aj zrieknutie sa pozostalostných pohl'adávok. ${ }^{24}$ Pretože in iure cessione pohl'adávky na cesionára prevoditel'né neboli, zanikali. In iure cessione sa cedent mohol zrieknut' iba výhod, ktoré mu pozostalost' prinášala, pozíciu dediča v dôsledku zásady semel heres semper heres už stratit' nemohol. Ako dedič preto zostal povinným z pozostalostných dlhov (ktoré in iure cessione prevoditel'né neboli).

Medzi úkonmi, smerujúcimi k prevodu pozostalosti, zaujímala in iure cessio hereditatis osobitné postavenie. Svedčí o tom aj nasledovný prípad, ${ }^{25} \mathrm{v}$ ktorom proti sebe stoja in iure

18 Gai. Inst. 2, 38. K tomu aj VOCI, c. d., s. 103.

19 Kobjektu in iure cessionis pozri aj ROBBE, La «hereditas iacet», s. 440; 471-473.

20 Okamih, po ktorom má in iure cessio popísané následky, označuje Gaius v Inst. 3, 85 slovami postea quam heres extiterit, v Inst. 2, 35 však uvádza post obligationem vero si cesserit. Prostredníctvom post obligationem chcel zdôraznit', že cesia bola vykonaná po prevzatí záväzkov (ku ktorému došlo prijatím dedičstva) a taktiež skutočnost', že tieto obligácie už nemôžu byt' in iure cessione prevedené na cesionára (nakol'ko sú už posudzované samostatne, nie ako súčast' celistvej hereditatis). Podobne ALBANESE, c. d., s. 56.

21 Pozri aj BUCKLAND, W. W. A Text-book of Roman Law from Augustus to Justinian. 3rd ed. revised by Peter Stein. Digitally printed version. Cambridge: University Press, 2007, s. 400.

22 Ulpianus 49 ad Sab. D. 18, 4, 2, 5; 8. K tomu bližšie TORRENT, Venditio hereditatis, s. 153 a nasl.

23 Zánik pozostalostných pohl'adávok nie je dosvedčený ani pri darovaní pozostalosti; porov. Papinianus 3 resp. D. 39, 5, 28.

24 Podobne KASER, M. Das römische Privatrecht. 1. Absch. Das altrömische, das vorklassische und klassische Recht. München: C. H. Beck, 1971, s. 722; LÜBTOW c. d., s. 330; PERNICE, A. Labeo. Römisches Privatrecht im ersten Jahrhundert der Kaiserzeit. Bd. 1. Neudruck der Ausgabe Halle 1873. Aalen: Scientia Verlag, 1963, s. 343; VOCI, c. d., s. 103; ROBBE, La «hereditas iacet», s. 477.

25 Plin. Ep. V, 1, 1: Legatum mihi obvenit modicum sed amplissimo gratius. Cur amplissimo gratius? Pomponia Galla exheredato filio Asudio Curiano heredem reliquerat me, dederat coheredes Sertorium Severum praetorium virum aliosque splendidos equites Romanos. Plin. Ep. V, 1, 2: Curianus orabat, ut sibi donarem portionem meam seque praeiudicio iuvarem; eandem tacita conventione salvam mihi pollicebatur. Plin. Ep. V, 1, 3: Respondebam non convenire moribus meis aliud palam aliud agere secreto; praeterea non esse satis honestum donare et locupleti et orbo; in summa non profuturum ei si donassem, profuturum si cessissem, esse autem me paratum cedere si inique exheredatum mihi liqueret. Plin. Ep. V, 1, 4: Ad hoc ille: 'Rogo cognoscas.' Cunctatus paulum 'Faciam' inquam; 'neque enim video cur ipse me minorem putem, quam tibi videor. Sed iam nunc memento non defuturam mihi constantiam, si ita fides duxerit, secundum matrem tuam pronuntiandi.' Plin. Ep. V, 1, 5: 'Ut voles' ait; 'voles enim quod aequissimum.' Adhibui in consilium duos quos tunc civitas nostra spectatissimos habuit, Corellium et Frontinum. Plin. Ep. V, 1, 6: His circumdatus in cubiculo meo sedi. Dixit Curianus quae pro se putabat. Respondi paucis ego - neque 
cessio a darovanie dedičského podielu: Pomponia Galla, ktorá vydedila svojho syna Asudia Curiana, ustanovila za dediča Plínia mladšieho a niekol'ko d'alších osôb. S úmyslom uplatnit' querelam inofficiosi testamenti ${ }^{26}$ požiadal Curianus Plínia, aby mu daroval svoj dedičský podiel (ut ... donarem portionem meam) a tým mu pomohol vytvorit’ praeiudicium pre centumvirov v spore proti ostatným dedičom. Účelu, ktorý sa Curianus snažil dosiahnut', by podl'a Plínia neprospelo darovanie, nakol'ko darovanie človeku bohatému a navyše bezdetnému nie je ušlachtilé. Sledovanému účelu by však zodpovedala in iure cessio, prostredníctvom ktorej by Plínius Curianovi cedoval nadobudnutý podiel ${ }^{27}$ (non profuturum ei si donassem, profuturum si cessissem). ${ }^{28}$ Plínius bol pripravený cesiu vykonat', ak sa preukáže, že Curianus bol svojou matkou vydedený nespravodlivo (esse autem me paratum cedere si inique exheredatum mihi liqueret). S ciel'om posúdit' dôvody vydedenia, vytvoril Plinius consilium, do ktorého prizval i dvoch vážených mužov obce. Záver konzília znel: Curianova matka mala spravodlivý dôvod hnevat' sa na Curiana. List d'alej pokračoval, jeho zvyšok však vo vzt’ahu k nášmu problému nie je relevantný. ${ }^{29}$

Plínius sa domnieval, že Curianovi by neprospelo darovanie dedičského podielu, lež jeho in iure cessio. In iure cessione by Plinius dal totiž najavo, že sa svojho dedičského podielu v prospech Curiana vzdáva, ${ }^{30}$ pretože jeho vydedenie bolo nespravodlivé. Tento Plíniov čin by mohol ovplyvnit' rozhodnutie centumvirov v spore začatom prostredníctvom querelae inofficiosi testamenti. Uvedený účel by však nedosiahli darovaním, s ktorým spoločenské povedomie nespájalo vzdanie sa dedičského podielu.

Zachované Plíniove svedectvo je nápomocné aj v inom ohl'ade. Vyššie bolo uvedené, že in iure cessio hereditatis ante aditionem bola mimoriadnym prostriedkom, ktorý umožňoval predíst' tomu, že poručitel' zostane bez dediča. Ante aditionem preto nebolo možné cedovat' pozostalost', ak bola legitima hereditas prijatá niektorým z ostatných povolaných agnátov, prípadne kým existovala možnost', že niektorý z povolaných dedičstvo prijme. Delácia nebola prevoditel’ná, kým cesia delácie nebola jediným zostávajúcim spôsobom ako sa vyhnút' tomu, že pozostalost' zostane bez dediča. In iure cessione ante aditionem nebolo možné na iného previest' právo stat' sa dedičom k podielu z pozostalosti. Vychádzajúc z Plíniovho listu však uvedené neplatilo, ak bola in iure cessio vykonaná post aditionem. Plínius bol jedným z viacerých, ktorí sa na základe testamentu dedičmi stali,

enim aderat alius, qui defunctae pudorem tueretur -, deinde secessi, et ex consilii sententia 'Videtur' inquam, 'Curiane, mater tua iustas habuisse causas irascendi tibi.' Post hoc ille cum ceteris subscripsit centumvirale iudicium, non subscripsit mecum.

26 K žalobe rovnako aj TELLEGEN, J. W. The Roman Law of Succession in the Letters of Pliny the Younger. I. Zutphen: Terra Publishing Co., 1982, s. 80-94; PERNICE, c. d., s. 342; ROBBE, La «hereditas iacet», s. 484; SOLAZZI, Diritto ereditario romano. I., s. 263.

27 Plínius i ostatní ustanovení dedičia svoj dedičský podiel už prijali, inak by bola querela inofficiosi testamenti zatial' neprípustná. Porov. však PERNICE, c. d., s. 343, p. 16.

28 „Cessissem“ odkazuje na in iure cessionem hereditatis aj podl'a ROBBE, La «hereditas iacet», s. 484-485; SOLAZZI, Diritto ereditario romano. I., s. 263-265.

29 Plíniov list, adresovaný Anniovi Severovi, pochádza podla TELLEGEN, The Roman Law of Succession in the Letters of Pliny the Younger, s. 82, z rokov 105-106. K samotnému sporu medzi vydedeným synom Curianom a osobami, ktoré Pomponia Galla vo svojom testamente ustanovila za dedičov, došlo v rokoch 93-96.

30 Podobne MELMOTH, W. Pliny Letters with an english translation by William Melmoth, revised by W. M. L. Hutchinson. London: William Heinemann - New York: The Macmillan co., 1931, s. 361, ktorý profuturum, si cessissem prekladá: ,if I were to renounce my legacy, that would advantage his claim.“ 
napriek tomu predpokladal, že cesia jeho dedičského podielu by bola platná. Post aditionem pravdepodobne mohol in iure cessionem vykonat' aj jeden zo spoludedičov, ktorý takto previedol čast' pozostalosti. Za dlhy pozostalosti by veritel'om zodpovedal nad'alej, pozostalostné pohl'adávky by cesiou zanikli. In iure cessione post aditionem sa už neprevádzala delácia, ktorá mohla byt’ prevedená iba vo výnimočnom prípade a preto odpadol aj dôvod, ktorý by vylučoval možnost' jej vykonania niektorým zo spoludedičov.

Zo zachovaných prameňov nevyplýva, že by in iure cessio hereditatis mohla byt' vykonaná iba bezprostredne po prijatí dedičstva, prípadne, že by jej uskutočnenie bolo inak časovo obmedzené. Do úvahy preto prichádza aj možnost', že dedič pozostalost' cedoval až po tom, ako boli pohl'adávky uspokojené a dlhy alebo zaplatené, alebo dal cesionár zábezpeku, že splnené budú. ${ }^{31}$

\section{In iure cessio hereditatis et heredes necessarii}

Gai. Inst. 2, 37: Idem et de necessariis heredibus diversae scholae auctores existimant, quod nihil videtur interesse, utrum <aliquis $>$ adeundo hereditatem statim fiat heres an invitus existat; quod quale sit, suo loco apparebit. sed nostri praeceptores putant nihil agere necessarium heredem, cum in iure cedat hereditatem.

Gai. Inst. 3, 87: Suus autem et necessarius heres an aliquid agant in iure cedendo, quaeritur. nostri praeceptores nihil eos agere existimant; diversae scholae auctores idem eos agere putant, quod ceteri post aditam hereditatem; nihil enim interest, utrum aliquis cernendo aut pro herede gerendo heres fiat an iuris necessitate hereditati adstringatur.

Na záver obidvoch pasáží pojednávajúcich o in iure cesii dedičstva zaradil Gaius zmienku o polemike medzi sabiniánmi a prokuliánmi dotýkajúcu sa platnosti in iure cessionis vykonanej nevyhnutným dedičom. Pri nevyhnutných dedičoch Gaius prirodzene nerozlišuje situáciu pred a po adícii, pretože nevyhnutní dedičia sa dedičmi stávali ihned' v okamihu delácie bez ohl'adu na svoju vôl'u. Do úvahy preto cesia prichádzala jedine po tom, ako sa dedičmi stali. Podl'a názoru prokuliánov (diversae scholae auctores) mohli nevyhnutní dedičia in iure cessionem vykonat', pretože nič nezáleží na tom, či sa niekto stane dedičom prijatím pozostalosti alebo proti svojej vôli. Sabiniáni (nostri praeceptores) in iure cessionem nevyhnutného dediča považovali za ničotnú.

Ked' vychádzame z vyššie uvedeného predpokladu, že in iure cessio hereditatis bola úkonom, ktorým sa cedent zriekal pozostalosti v prospech cesionára, pričom jej následky záviseli od toho, či sa už dedičom stal, alebo nie, zdá sa byt’ logickým dôsledkom, že heredes necessarii in iure cessionem uskutočnit' nemohli. Dedičmi sa stávali nevyhnutne, sive velint, sive nolint. Okamihom delácie boli k pozostalosti pripútaní iuris necessitate. Iure civili sa o prijatí, či odmietnutí dedičstva slobodne rozhodnút' nemohli. Myšlienka, že by sa nevyhnutný dedič mohol vzdat' pozostalosti v prospech niekoho iného v sebe preto obsahuje vnútorný protiklad. Čo primälo prokuliánov, aby mali na vec odlišný názor?

31 Tak aj SOLAZZI, Diritto ereditario romano. I., s. 264 a nasl., ktorý uvedené predpokladá aj vo vyššie citovanom prípade Plínia mladšieho. Vychádzajúc z: Scis te non subscripsisse mecum, et iam biennium transisse omniaque me usu cepisse. (Plin. Ep. V, 1, 10), považuje za možné, že Plínius list písal po uplynutí dvoch rokov od prijatia dedičstva. Na uhradenie pohl'adávok a zaplatenie dlhov bolo teda dost' času. In iure cessio už nepredstavovala riziko ani pre cedenta, ani pre cesionára. 
A dotýkal sa tento ich názor obidvoch kategórií nevyhnutných dedičov, alebo iba vlastných nevyhnutných dedičov (sui et necessarii)?

Inst. 2, 37 a Inst. 3, 87 nie sú terminologicky totožné. Zatial’ čo v Inst. 2, 37 Gaius hovorí všeobecne o nevyhnutných dedičoch (heredes necessarii), ${ }^{32}$ v Inst. 3, 87 bez akéhokol'vek sprievodného vysvetlenia priamo uvádza: suus autem et necessarius heres an aliquid agant in iure cedendo, quaeritur. Namiesto heredes necessarii je v Inst. 3, 87 objektom polemiky suus et necessarius heres. Gaius tam vypúšt’a i poznámku quod quale sit, suo loco apparebit.

Pod pojmom heredes necessarii (Inst. 2, 37) možno rozumiet' všetkých tých, ktorí sa stávali dedičmi nevyhnutne. V rámci nevyhnutných dedičov Gaius rozlišuje dve podkategórie: heredes autem aut necessarii dicuntur aut sui et necessarii; ${ }^{33}$ dedičia sú bud' nevyhnutní, alebo vlastní a nevyhnutní. „Iba“ nevyhnutným dedičom bol otrok ustanovený v testamente za dediča a súčasne prepustený na slobodu. ${ }^{34}$ Ostatných nevyhnutných dedičov, tj. rodinných príslušníkov zomretého, ktorí boli v čase smrti poručitel’a bezprostredne podriadení jeho moci, nazýva Gaius sui et necessarii heredes, pričom v Inst. 2, 156 ich charakteristiku začína slovami sui autem et necessarii heredes sunt. ${ }^{35}$ Až na množné číslo teda rovnakými slovami, aké používa v Inst. 3, 87.

V Inst. 3, 87 si možno všimnút plurál, ktorý nezodpovedá úvodnému suus et necessarius heres.

Suus autem et necessarius heres an aliquid agant in iure cedendo, quaeritur. nostri praeceptores nihil eos agere existimant; diversae scholae auctores idem eos agere putant, quod ceteri post aditam hereditatem; nihil enim interest, utrum aliquis cernendo aut pro herede gerendo heres fiat an iuris necessitate hereditati adstringatur.

Uvedený nekorešpondujúci plurál je jedným z argumentov tých autorov, podl'a ktorých sa kontroverzia dotýkala obidvoch podkategórií nevyhnutných dedičov. Plurál eos má nasvedčovat' tomu, že aj v úvode Inst. 3, 87 boli pôvodne uvedené dva subjekty. Solazzi ${ }^{36}$

32 Je nepravdepodobné, že sa heredes necessarii v Inst. 2, 37 malo vzt’ahovat' iba na otroka ako dediča nevyhnutného (heres necessarius v užšom zmysle). Aj v Inst. 2, 58 a Inst. 3, 201 (2×) používa Gaius toto označenie, pričom má na mysli obidve kategórie nevyhnutných dedičov. Ak by sa polemika prokuliánov a sabiniánov dotýkala iba nevyhnutných dedičov v užšom zmysle, zrejme by sa Gaius o vlastných dedičoch zmienil. K tomu zhodne NELSON, H. L. W. - MANTHE, U. Gai Institutiones III 1-87. Intestaterbfolge und sonstige Arten von Gesamtnachfolge. Text und Kommentar. Berlin: Duncker \& Humblot, 1992, s. 211; KRÜGER, H. Die usucapio pro herede nach klassischem Recht. ZSS, 1934, 54, s. 97; FRANCIOSI, G. Usucapio pro herede. Contributo allo studio dell'antica hereditas. Napoli: Casa editrice Dott. Eugenio Jovene, 1965, s. 12.

33 Gai. Inst. 2, 152.

34 Gai. Inst. 2, 153: Necessarius heres est servus cum libertate heres institutus, ideo sic appellatus, quia sive velit sive nolit, omni modo post mortem testatoris protinus liber et heres est.

35 Gai. Inst. 2, 156: Sui autem et necessarii heredes sunt velut filius filiave, nepos neptisve ex filio, $<$ et $>$ deinceps ceteri, qui modo in potestate morientis fuerunt. sed uti nepos neptisve suus heres sit, non sufficit eum in potestate avi mortis tempore fuisse, sed opus est, ut pater quoque eius vivo patre suo desierit suus heres esse aut morte interceptus aut qualibet ratione liberatus potestate; tum enim nepos neptisve in locum sui patris succedunt. Gai. Inst. 2, 157: Sed sui quidem heredes ideo appellantur, quia domestici heredes sunt et vivo quoque parente quodam modo domini existimantur; unde etiam si quis intestatus mortuus sit, prima causa est in successione liberorum. necessarii vero ideo dicuntur, quia omni modo, velint <nolint, tam> ab intestato quam ex testamento heredes fiunt.

36 SOLAZZI, Diritto ereditario romano. I., s. 260-261. Obdobne ROBBE, La «hereditas iacet», s. 470. 
úvod rekonštruuje: suus autem et servus necessarius heres an aliquid agant; ${ }^{37}$ vypadnutie slova servus by nemalo byt' prekvapivé, predsa sa obvykle používalo spojenie suus et necessarius. Možná bola podl'a Solazziho aj verzia suus autem aut necessarius heres an aliquid agant. ${ }^{38}$

Nelson a Manthe v komentári ku Gaiovým Inštitúciám v Inst. 3, 87 namiesto agant uvádzajú $a g a:{ }^{39}$ v pluráli tak zostáva iba zámeno eos. Spor sa podl'a nich mal dotýkat' iba vlastných nevyhnutných dedičov (sui et necessarii), nakol'ko je pochybné, že by tu Gaius chcel dat' slovám suus et necessarius heres význam, ktorý je v nevysvetlitel'nom rozpore s jeho definíciou obsiahnutou v Inst. 2, 156. S tým možno súhlasit'. Je nepravdepodobné, že by rímski právnici zastávali tézu, v zmysle ktorej by otrokom (necessarii tantum) mohlo byt' priznané právo in iure cessionis hereditatis. Slobodnými sa stali len vd'aka tomu, že boli súčasne i ustanovení za dedičov. Skutočnost', že v Inst. 2, 37 Gaius používa výraz necessarii bez bližšieho spresnenia (sui et), možno vysvetlit' jeho poznámkou quod quale sit, suo loco apparebit. Gaius tu oznamuje, že otázku ozrejmí neskôr na vhodnom mieste (Gai. Inst. 2, 152-160). Až po tomto objasnení bude čitatel' vediet', že nevyhnutní dedičia sa rozdel’ujú do dvoch tried. Zjavne vychádzal Gaius z toho, že neskôr (v Inst. 3, 87) upresní, ktorú z daných dvoch tried mali prokuliáni a sabiniáni na mysli, ked' sa sporili o platnost' in iure cessionis hereditatis. ${ }^{40}$ Polemika medzi prokuliánmi a sabiniánmi sa dotýkala iba vlastných nevyhnutných dedičov.

Téza, s ktorou prišli prokuliáni, bola novou, ${ }^{41}$ preto Gaius na obidvoch miestach vo svojej učebnici uvádza iba argumenty prokuliánov. V prípade sabiniánov len poznamenáva, že v súlade s ich názorom nevyhnutný dedič in iure cedendo nič nespôsobí. Nebolo potrebné odôvodňovat' dlhodobo zachovávaný názor, ktorého dôvody boli všeobecne známe.

Skutočnost', že prokuliáni vlastným nevyhnutným dedičom (heredes sui et necessarii) priznali právo in iure cessionis, súvisí pravdepodobne s vývojom právneho postavenie týchto dedičov v práve prétorskom. ${ }^{42}$ Hoci iure civili medzi „vlastnými nevyhnutnými“ a „,iba nevyhnutnými“ dedičmi rozdiel nebol (obidve skupiny sa stávali dedičmi etiam inviti), ${ }^{43}$ prétor prvej skupine poskytoval väčšiu ochranu. Vlastnému nevyhnutnému dedičovi priznával beneficium abstinendi ${ }^{44}$ ktoré malo účinky podobné odmietnutiu pozosta-

37 S poukazom na Ulpianus 4 ad ed. D. 2, 14, 7, 18: [...] Marcellus autem libro octavo decimo digestorum et suum heredem et servum necessarium pure scriptos, paciscentes priusquam se immisceant putat recte pacisci, $[\ldots]$.

38 S odvolaním na D. 30, 68, 1: si suus heres aliquis aut necessarius [...] ex eo testamento factus erit.

39 NELSON - MANTHE, $c$. $d$., s. 47.

40 Podobne NELSON - MANTHE, c. d., s. 209-211.

41 NELSON - MANTHE, $c$. d., s. 211-212: Do rozporu so sabiniánmi sa prokuliáni dostali až niekedy v prvej polovici 1. st. po Kr., v dôsledku učenia Labeóna a Procula. Podobne SOLAZZI, Diritto ereditario romano. I., s. 262-263. Pôvodné odopretie in iure cessionis vo vzt'ahu k nevyhnutným dedičom bolo aj v záujme veritel'ov. Tak suus ako aj servus necessarius by po eventuálnom scudzení corporum hereditatis, neboli spôsobilí uspokojit' veritel’ov zomretého.

42 Tak aj NELSON - MANTHE, c. d., s. 211-212.

43 Ulp. lib. sing. 22, 24: Inter necessarios heredes, id est servos cum libertate heredes scriptos, et suos et necessarios, id est liberos, qui in potestate sunt, iure civili nihil interest: nam utrique etiam inviti heredes sunt. [...].

$44 \quad$ Ulp. lib. sing. 22, 24: [...] Sed iure praetorio suis et necessariis heredibus abstinere se a parentis hereditate permittitur; necessariis autem tantum heredibus abstinendi potestas non datur. 
losti. Iure civili zostal suus et necessarius síce dedičom, prétor ho však chránil tak, akoby dedičom nebol. ${ }^{45}$ Servus necessarius podobnú výhodu nemal. ${ }^{46}$ Prétor mu síce priznával beneficium separationis bonorum, toto však ani iure praetorio nemalo charakter odmietnutia dedičstva. Umožňovalo mu iba obmedzit' jeho zodpovednost' za pozostalostné dlhy do výšky pozostalostného majetku. ${ }^{47}$ Prétorom modifikované postavenie vlastných nevyhnutných dedičov mohlo motivovat' prokuliánov, aby aj vo vzt'ahu $\mathrm{k}$ in iure cesii ich postavenie priblížili dedičom dobrovol'ným.

Ulpiani liber singularis regularum o polemike medzi prokuliánmi a sabiniánmi mlčí, o in iure cesii vykonanej nevyhnutným dedičom sa nezmieňuje vôbec. Osobitne sa nezmieňuje ani o cesii, ktorú by pred adíciou vykonal dedič povolaný testamentom. Uspokojil sa s tým, že takúto eventualitu vylúčil ihned' v úvode slovami antequam adeatur, in iure cedi potest legitimo ab herede. In iure cessionem hereditatis, ktorú by pred adíciou vykonal dedič ustanovený v testamente nespomína, pretože bola neprípustná. Možno takýto záver vyvodit’ i z jeho mlčania o cesii vykonanej vlastným nevyhnutným dedičom? Ak áno, znamená to, že názor prokuliánov sa nepresadil. I napriek postupnému zbližovaniu systému civilného a prétorského práva, a navzdory niekol'kým ústupkom, ${ }^{48}$ zostali sui et necessarii ešte aj v justiniánskom práve nevyhnutnými dedičmi. ${ }^{49}$ To svedčí o hlboko zakorenenom vnímaní takéhoto ich postavenia, z ktorého pramenila nevôl'a aj voči takému, pomerne miernemu ústupku, akým by bola in iure cessio hereditatis post aditionem. Tak ako podl'a civilného práva nemohli odmietnut' dedičstvo, nemohli sa ho, hoci len s obmedznými účinkami, ani zrieknut' v prospech niekoho iného.

\section{Záver}

Pred prijatím pozostalosti bol k vykonaniu in iure cessionis hereditatis oprávený iba heres voluntarius povolaný $\mathrm{k}$ dedeniu zákonom. Vykonanou in iure cesiou prevádzal na iného delatam hereditatem - právnu možnost' stat' sa dedičom. Cesionár nadobúdal dedičstvo v dôsledku samotnej cesie, následná adícia sa nevyžadovala, pretože svoju vôl'u byt'

45 Gaius 23 ad ed. provinc. D. 29, 2, 57 pr.: Necessariis heredibus non solum impuberibus, sed etiam puberibus abstinendi se ab hereditate proconsul potestatem facit, ut, quamvis creditoribus hereditariis iure civili teneantur, tamen in eos actio non detur, si velint derelinquere hereditatem. Paulus 17 ad ed. D. 11, 1, 12 pr.: [...] quia hunc qui abstinuit praetor non habet heredis loco. K tomu pozri aj ŚWIRGOŃ-SKOK, R. Ograniczenie odpowiedzialności dziedziców koniecznych (heredes necessarii) za długi spadkowe w rzymskim prawie klasycznym. In: Quid leges sine moribus? Studia nad prawem rzymskim dedykowane Prof. M. Kuryłowiczowi w 65. rocznice urodzin oraz 40-lecie pracy naukowej. Lublin: Wydawnictwo Uniwersytetu Marii Curie-Skłodowskiej, 2009, s. 152. Nebolo potrebné, aby sa suus et necessarius heres so žiadost'ou o beneficium abstinendi osobitne obracal na prétora. Stačilo, ak sa do dedičstva nevmiešal. Ulpianus 11 ad ed. D. 29, 2, 12: Ei, qui se non miscuit hereditati paternae, sive maior sit sive minor, non esse necesse praetorem adire, sed sufficit se non miscuisse hereditati. [...]; Gaius 23 ad ed. provinc. D. 29, 2, 57 pr.; Ulpianus 61 ad ed. D. 29, 2, 71, 4: Si quis suus se dicit retinere hereditatem nolle, aliquid autem ex hereditate amoverit, abstinendi beneficium non habebit.

46 Ulp. lib. sing. 22, 24.

47 Gai. Inst. 2, 154-155. K tomu pozri aj ŚWIRGOŃ-SKOK, c. d., s. 153 a nasl.

48 Okrem beneficii abstinendi, i právom uznaná možnost' ustanovit' suos pod potestatívnou podmienkou: Maecenatus 7 fideic. D. 28, 5, 87 (86) pr.; Maecenatus 7 fideic. D. 28, 5, 87, 1; Hermogenianus 3 iuris epit. D. 28, 7, 12 .

49 Rozlišovanie medzi dobrovol’nými a nevyhnutnými dedičmi ešte aj v Just. Inst. 2, 19. K tomu aj VOCI, c. d., s. 586 . 
dedičom vyjadril už participáciou na cesii. Okamihom uskutočnenia in iure cesie sa cesionár stal dedičom, akoby bol k dedeniu sám povolaný zákonom.

Post aditionem bola in iure cessio hereditatis prístupná tak dedičovi intestátnemu, ako aj testamentárnemu. Nakol'ko sa uskutočňovala po tom, ako sa cedent adíciou dedičom stal, v dôsledku zásady semel heres semper heres nemohol svoje dedičské postavenie už previest' na cesionára. Hereditas sa v osobe cedenta-dediča rozložila na svoje jednotlivé komponenty - práva, povinnosti a corpora. Hoci sa ako dedič nemohol zbavit' svojich povinností voči pozostalostným veritel'om, mohol sa prostredníctvom cesie zriect' výhod, ktoré mu pozostalost' prinášala - pozostalostných pohl'adávok a rerum corporalium. Z nich však iba res corporales boli spôsobilým objektom in iure cesie. V in iure cesii obsiahnuté vzdanie sa pozície dediča spôsobilo, že pozostalostné pohl'adávky zanikli a dlžníci tak dosiahli zisk.

Spornou bola medzi prokuliánmi a sabiniánmi účinnost' in iure cesie vykonanej vlastným nevyhnutným dedičom (heres suus et necessarius). In iure cessio hereditatis bola vnímaná ako vzdanie sa dedičstva a preto bol takýto úkon pôvodne vylúčený vo vzt’ahu k obidvom kategóriám nevyhnutných dedičov (servi necessarii a sui et necessarii), ktorí dedičstvo odmietnut' nemohli, pretože dedili etiam inviti. Nevyhnutné dedičské postavenie vlastných nevyhnutných dedičov bolo však v priebehu času zmiernené prétorom, ktorý im priznával beneficium abstinendi - právo iure praetorio dedičstvo odmietnut'. Táto skutočnost' motivovala prokuliánov $\mathrm{k}$ tomu, aby in iure cesii vykonanej vlastným nevyhnutným dedičom priznali tie isté účinky, aké mala in iure cessio post aditionem vykonaná dedičom dobrovol'ným. Neskorší Ulpiani liber singularis regularum sa o in iure cesii nevyhnutných dedičov nezmieňuje, z čoho možno usúdit', že názor prokuliánov sa nepresadil. 